\begin{tabular}{lllllllllll}
\hline M & I & S & C & E & L & L & A & N & E & A
\end{tabular}

KAMILA RADECKA-MIKULICZ

Instytut Historii im. T. Manteuffla Polskiej Akademii Nauk

\title{
OBRAZ ŻYCIA CODZIENNEGO W CHEŁMIE W 1928 ROKU NA PODSTAWIE RUBRYKI FUN CHEEM UN UMGEGENT (Z CHEŁMA I OKOLICY) PUBLIKOWANEJ NA ŁAMACH TYGODNIKA „CHEEMER SZTYME” (GEOS CHEŁMA)
}

Zarys treści: W artykule szkicuję obraz życia codziennego żydowskich mieszkańców Chełma w 1928 r., wykorzystując informacje zawarte w stałej rubryce Fun Chetm un umgegent (Z Chełma i okolicy), publikowanej na łamach tygodnika „Chełmer Sztyme” (Głos Chełma). Czasopismo ukazywało się w latach 1924-1939, w artykule koncentruje się jednak na jednym roczniku - 1928. Ograniczenie się do wybranej rubryki jednego rocznika pozwoliło mi na wstępne rozpoznanie języka gazety i jej perspektywy w opisywaniu wycinka miejskiej rzeczywistości. Tekst ma charakter przyczynkarski i jego głównym celem jest rekonesans możliwości wykorzystania prasy w tworzeniu monografii chełmskiej społeczności żydowskiej.

The content outline: The aim of this article is to outline everyday life of Jewish inhabitants of Chełm in 1928, on the basis of the column "Fun Chełm un umgegent" (From Chełm and Its Neighbourhood) published in the Khelemer Shtime (The Voice of Chełm) weekly. The newspaper was issued between 1924 and 1939, but for the purpose of this paper I have decided to focus on issues from one year exclusively - 1928. This restraint enables to examine magazine's language and its perspective in the town's depiction. Additional goal of this paper is to identify the possibility of the use of Yiddish press in developing a monograph, devoted to Jewish inhabitants of Chełm in the inter-war period, in the field of social history.

Słowa kluczowe: Żydzi, Chełm, okres międzywojenny, 1918-1939, prasa żydowska

Keywords: Jews, Chełm, inter-war period, 1918-1939, Jewish press 


\section{Wstęp}

Celem niniejszego artykułu jest naszkicowanie obrazu życia codziennego żydowskich mieszkańców Chełma, jaki wyłania się z lektury stałej rubryki Fun Chetm un umgegent (Z Chełma i okolicy), publikowanej na łamach tygodnika „Chełmer Sztyme” (Głos Chełma). Temat międzywojennego życia miasta był już kilkukrotnie podejmowany. Niektórzy badacze pochylali się także nad dziejami chełmskiej społeczności żydowskiej, jednak żaden z nich nie sięgną dotąd do wydawanej w mieście prasy w języku jidysz - i właśnie korzystanie z tego nieocenionego źródła wyróżnia moje podejście badawcze.

Analizę treści kolejnych roczników „Chełmer Sztyme” oraz innych chełmskich gazet żydowskich starałam się koncentrować wokół kilku bloków zagadnień:

1) tożsamości Żydów chełmskich - w jaki sposób opisywali swoją społeczność; jak definiowali tożsamość żydowską?; czy pojawiały się wątki dotyczące procesów i debat autoemancypacyjnych, asymilacyjnych; kreślące konkretne wizjie przyszłości chełmskiej mniejszości żydowskiej?1;

2) struktury społecznej - na ile chełmska społeczność żydowska była wewnętrznie zróżnicowana?; czy zauważalne były grupy wykluczone, a jeśli tak, to kto się do nich zaliczał?; jakie miejsce w społeczności zajmowały kobiety??; jakie były kierunki przemian środowiska żydowskiego i jak były one postrzegane przez samych Żydów?;

3) sieci instytucji życia publicznego: partii politycznych, organizacji społecznych, oświatowych, instytucji dobroczynnych etc.;

4) roli Żydów w kształtowaniu miasta i jego życia politycznego, społecznego, kulturalnego, gospodarczego; jak ją widzieli i opisywali?; jakie były punkty styku, współpracy, konkurencji między zamieszkującymi Chełm społecznościami: żydowska, polską i ukraińska; na ile możliwe będzie ich wskazanie na podstawie zapisów prasowych; jaka była charakterystyka tych korelacji?;

\footnotetext{
1 Żydzi jako mniejszość narodowa podlegali z pewnością wpływom społeczności większościowej; zob. M. Mandel, Assimilation and Cultural Exchange in Modern Jewish History, w: Rethinking European Jewish History, red. J. Cohen, M.J. Rosman, Oxford 2014, s. 73.

${ }^{2}$ Pytanie to dotyczy przede wszystkim reprezentacji tzw. zwyczajnych kobiet. Według M.J. Rosmana (zob. tenże, How Jewish is Jewish History, Oxford 2007, s. 173) historiografia zauważała już wcześniej postaci kobiet wybitnych, mnie szczególnie interesuje więc rola kobiet zazwyczaj niezauważanych i pomijanych, choć oczywiście kobiety żydowskiej elity Chełma również znajdą swoje miejsce w mojej pracy.
} 
5) życia codziennego Żydów chełmskich i ich wpływu na przestrzeń miejska, w dni powszednie i świąteczne;

6) szczegółowym, ale istotnym było też dla mnie pytanie o sprawy związane z chasydyzmem - czy w Chełmie mieszkali chasydzi, a jeśli tak, to których dynastii byli wyznawcami?

W tym miejscu warto zwrócić uwagę, że udzielenie wyczerpującej odpowiedzi na powyższe pytania wymaga wykorzystania pełnej palety dostępnych źródeł. Artykuł prezentuje wyniki rekonesansu badawczego, który pozwoli na przygotowanie bardziej dojrzałych narzędzi analizy społeczności Żydów w międzywojennym Chełmie. Wydaje się jednak, że już wstępne wnioski sformułowane na podstawie kwerendy wybranych numerów pisma warte są publikacji i dyskusji.

\section{Prasa żydowska w Chełmie}

Międzywojenna prasa żydowska tworzona była przez Żydów i do nich też była adresowana. Taka perspektywa pozwala wejrzeć w życie społeczności żydowskiej „od środka”. Inne źródła, np. wytwarzane przez funkcjonariuszy instytucji miejskich czy państwowych, ujmowały przejawy życia społecznego z perspektywy zewnętrznej, do tego często w sposób uproszczony i schematyczny, nieuwzględniający specyfiki tej społeczności.

Mimo burz dziejowych i zniszczeń wojennych do dziś zachowało się stosunkowo wiele numerów żydowskiej prasy lokalnej wydawanej w okresie międzywojennym. Pozostaje ona en masse niezbadaną. Według Adama Kopciowskiego ${ }^{3}$ taka sytuacja dotyczy stanu badań prasy żydowskiej wydawanej w większości ośrodków miejskich Lubelszczyzny - nie inaczej wygląda to w Chełmie ${ }^{4}$. W żadnej z dotychczasowych publikacji poświęconych mieszkańcom Chełma, w szczególności Żydom ${ }^{5}$, nie natrafiłam na odesłanie do wydawanych w mieście czasopism żydowskich.

\footnotetext{
${ }^{3}$ A. Kopciowski, Wos hert zich in der prowinc? Prasa żydowska na Lubelszczyźnie i jej największy dziennik „Lubliner Tugblat”, Lublin 2015, s. 10.

${ }^{4}$ Dotychczasowy stan badań prasy chełmskiej obejmuje rozdział o chełmskiej prasie w: tamże, s. 153-165.

${ }_{5}^{5}$ Por. P. Kiernikowski, Miasto Chetm $w$ okresie międzywojennym (1918-1939), Chełm 2007; Z. Lubaszewski, Spacerkiem po Chełmie, Chełm 2014; K. Mart, Z. Lubaszewski, Żydzi w Chetmie, Chełm 2010; R. Kuwałek, Żydowskie Gminy Wyznaniowe $w$ powiecie chetmskim w latach 1918-1939, „Rocznik Chełmski” 1, 1995, s. 217-244; K. Zieliński, Ludność żydowska w powiecie chetmskim w latach 1914-1918. Studium statystyczne, „Rocznik Chełmski” 2, 1996, s. 185-205; tenże, Żydzi chetmscy w latach 1912-1918, „Rocznik Chełmski” 3, 1997, s. 203-230; P. Kiernikowski, Mieszkańcy
} 
Jednym z najważniejszych czasopism wydawanych w Chełmie był tygodnik „Chełmer Sztyme”. Redakcja określała tygodnik jako bezpartyjny, o czym informowała w winiecie. Pismo koncentrowało się na podawaniu informacji z miasta i jego najbliższej okolicy (kolportaż docierał do kilku innych miejscowości regionu). Pole zainteresowań pisma nie było zawężone wyłącznie do tematyki żydowskiej. W omawianej przeze mnie rubryce Fun Chetm un umgegent znaleźć można m.in. sprawozdania z kolejnych posiedzeń rady miasta (w której istotną rolę odgrywali chełmscy Żydzi), informacje dotyczące rozwoju infrastruktury Chełma, wprowadzanych nowych przepisów, podatków itd. Ponadto wiadomości o wypadkach żydowskich, polskich i ukraińskich mieszkańców miasta i okolicy.

Pierwszy numer tygodnika wydano 19 III 1924 r., ostatni 8 IX 1939 r. - łącznie ukazały się 794 numery. Najstarszy numer czasopisma, przechowywany w Bibliotece Narodowej, ukazał się 6 I 1928 r. - i to właśnie jego lektura stała się inspiracją dla niniejszego artykułu.

\section{„Chełmer Sztyme” i jego rubryka Fun Chetm un umgegent}

Omawiana rubryka Fun Chetm un umgegent, zawierajaca informacje $\mathrm{z}$ miasta i jego okolicy, jak w soczewce skupia zainteresowania całego czasopisma. Kolumna lokalizowana była na różnych stronach, a w poszczególnych numerach zmieniała się jej objętość - od jednego artykułu (czasem obszernej relacji, czasem krótkiej wzmianki) do kilkunastu tekstów różnej długości.

Tematy pojawiajace się w rubryce uporządkowałam według następujaccych kategorii:

a) życie polityczne, w tym: regulacje miejskie, jak np. dotyczące świąt państwowych, wspólne inicjatywy ${ }^{7}$; również informacje na temat poboru do wojska, wyborów do rady miasta i na szczeblu państwowym;

b) życie religijne, w tym: działalność żydowskiej gminy wyznaniowej oraz podlegajacych jej instytucji dobroczynnych; informacje o obchodzonych

miasta Chetma $w$ latach 1914-1939. Struktura demograficzna i etniczna, „Rocznik Chełmski" 6, 2000, s. 71-88.

${ }^{6}$ Mimo niewielkiego nakładu, liczącego 300-400 egz. Inne to: „Unser Cukunft” maj 1927, wydawnictwo jednorazowe; „Chełmer Folksblat” 1928-1931; „Chełmer Wochenblat” 1930-1933; „Echa Szkolne” 1922-1925.

7 Interesującą deklarację współpracy bloku mniejszości zrzeszającejŻydówi Ukraińców mieszkających w Chełmie znajdziemy w „Chełmer Sztyme” 1928, nr 9 (155). 
świętach żydowskich, a także funkcjonujących w mieście sztiblach chasydzkich;

c) życie kulturalne i edukacja, w tym: odczyty i akademie ${ }^{8}$;

d) życie gospodarcze, w tym: odgórne zarządzenia (np. dotyczące ustalania cen), informacje administracyjne (np. na temat działalności Zwiąku Kupieckiego), rozwoju infrastruktury miasta;

e) wypadki i sensacje, w tym: wypadki śmiertelne, katastrofy budowlane, wypadki komunikacyjne, bójki, kradzieże, anomalie pogodowe; również zjawiska niewyjaśnione ${ }^{9}$.

\section{Omówienie wybranych tematów z 1928 r. w porządku problematycznym}

\section{Życie polityczne}

Życie polityczne międzywojennego Chełma zostało udokumentowane $\mathrm{w}$ archiwaliach wytworzonych przez magistrat. Zestawione $\mathrm{z}$ nimi informacje prasowe ukażą kontekst utrwalonych wydarzeń i poprzedzających je przygotowań czy sporów. Podrozdział podzieliłam na punkty: miejskie życie polityczne, krajowe życie polityczne, święta oraz uroczystości państwowe i miejskie.

\section{Miejskie życie polityczne}

Informacje przyporządkowane do tej kategorii dotyczą głównie przebiegu posiedzeń rady miasta oraz wyników jej uchwał. Rada miasta spotykała się $\mathrm{z}$ reguły raz $\mathrm{w}$ miesiącu, wyjątkiem był styczeń (dwa zebrania), czerwiec (cztery burzliwe zebrania z głosowaniem nad budżetem miasta) oraz sierpień i grudzień (kiedy zebrań nie było). Tygodnik donosił nie tylko o podjętych uchwałach i wyborach (o których wiemy z innych źródeł), ale też kuluarowych plotkach i napięciach. Dzięki rubryce wiemy, że w styczniowych wyborach rozkład sił politycznych rysował się następująco: pierwszym klubem była Polska Partia Socjalistyczna, potem Żydowski Klub Lewicowy, Polski Klub Prawicowy, wreszcie radni z Bloku Nacjonalistycznego.

${ }^{8}$ Informacje o repertuarze kin i teatrów czy innego rodzaju występach znajdują na innych stronach gazety.

${ }^{9}$ Zainteresowanych historią drzwi straszących mieszkańców jednego z domów odsyłam do „Chełmer Sztyme” 1928, nr 39 (183). 
Dzięki dziennikarzom „Chełmer Sztyme” znamy również nazwiska najaktywniejszych radnych żydowskich w 1928 r. Byli to: Lederman z Prawicowego Klubu Żydowskiego (ponadto prezes Zarządu Związku Kupców w Chełmie) ${ }^{10}$, Fruchtgarten z Bundu ${ }^{11}$ oraz Iwry z Poalej Syjon Lewicy ${ }^{12}$. Poza wymienionymi w skład rady wchodzili również przedstawiciele PPS, Żydowskiego Klubu Lewicowego, Polskiego Klub Prawicowego oraz Żydowskiego Bloku Nacjonalistycznego. Mimo tego pluralistycznego składu rady, radny Fruchtgarten podniósł wątek antysemickiego charakteru polityki zatrudnienia $\mathrm{w}$ magistracie ${ }^{13}$, czego dowodem był fakt, że na 74 zatrudnionych urzędników jedynie dwóch było Żydami.

"Chełmer Sztyme” informował czytelników o przyznanych przez radę miasta subwencjach dla instytucji żydowskich, dzięki czemu mamy dostęp do listy stowarzyszeń działajacych w mieście w 1928 r. Jedna z najważniejszych była Folks-szule (szkoła podstawowa pod auspicjami $\mathrm{CISZO}^{14}$, z językami polskim i jidysz jako wykładowymi - dofinansowanie 4000 zł). O konieczności jej dofinansowania przekonywał jeszcze w styczniu radny Iwry, który podkreślał jej fatalne uposażenie finansowe i zagrożenie eksmisją ${ }^{15}$, również radny Fruchtgarten wskazywał na konieczność wstrzymania eksmisji szkoły; w omawianym roku szkoła świętowała dziesiątą rocznicę swojego istnienia w Chełmie. Przy chełmskiej gminie wyznaniowej działały towarzystwa dobroczynne: Linas Hacedek zajmujące się ubogimi chorymi (otrzymało dofinansowanie w wysokości 4000 zł); dom starców dla ubogich Żydów - Moszaw Zkenim (2000 zł); Stowarzyszenie Bejt Lechem, zajmujace się wspomaganiem ubogich żywnościa, szczególnie w okresach świątecznych (1000 zł). Spośród organizacji kulturalno-oświatowych dofinansowano (każde kwota 1500 zł): Kultur-Lige, Stowarzyszenie Kursów Wieczorowych, Bibliotekę Pereca, w której odbywało się wiele imprez kulturalnych, również opisywanych w rubryce Fun Chetm un umgegent. Najwyższe dofinansowanie (w wysokości 3000 zł) uzyskało gimnazjum

\footnotetext{
${ }^{10}$ „Chełmer Sztyme” 1928, nr 1 (147); nr 25 (171); nr 33 (177); nr 41 (185); nr 45 (189).

11 „Chełmer Sztyme” 1928, nr 1 (147); nr 25 (171); nr 26 (172).

12 „Chełmer Sztyme” 1928, nr 1 (147).

13 „Chełmer Sztyme” 1928, nr 26 (172).

${ }^{14}$ Centrale Jidysze Szul Organizacje - Centralna Żydowska Organizacja Szkolna, świecka, jidyszystyczna organizacja oświatowa działająca od 1921 r. W 1928 r. funkcjonowała również dzięki dofinansowaniom American Jewish Joint Distribution Committee, który wspierał materialnie też chełmską placówkę.

15 „Chełmer Sztyme” 1928, nr 1 (147).
} 
żydowskie. Rada miasta dofinansowała instytucje żydowskie łączną kwota 18500 zł. Niestety, gazeta nie podała, jaki był to procent wszystkich dofinansowań ${ }^{16}$.

Od stycznia w Chełmie działał „Bezpartyjny komitet ludowy zwolenników rządów marszałka Piłsudskiego" ${ }^{17}$. W odezwie opublikowanej w rubryce Fun Chetm un umgegent pisano: „Chcemy pokojowego życia z innymi mniejszościami narodowymi, pod warunkiem: całkowitej lojalności wobec rządu. Stoimy na stanowisku zabezpieczania polityki mniejszości narodowych w zakresie wolności ekonomicznego, wyznaniowego i narodowego rozwoju - w granicach polskiej konstytucji”. Wśród członków komitetu z okręgu lubelskiego znaleźli się dwaj chełmianie (polskiego pochodzenia) - dyrektor gimnazjum i radny Ambroziewicz oraz radny Zajdler. Co zaskakujące, nie znalazłam informacji, by w skład komitetu wchodzili chełmscy Żydzi.

W kilku numerach przewijaja się informacje o zarządzeniach odgórnie regulujacych miejskie życie ${ }^{18}$, jak np. ustalajace godziny otwarcia zakładów takich jak fotograf, jatka czy budka $\mathrm{z}$ wodą sodowa ${ }^{19}$. W ślad za tym pojawiały się również informacje o wykroczeniach przeciwko tym regulacjom ${ }^{20}$. W 1928 r. skala wykroczeń przeciwko: regulaminowi sanitarnemu dotyczącemu hoteli, pokoi umeblowanych czy zakładów fryzjerskich, regulaminowi porządkowemu dotyczącemu funkcjonowania biur, skarbca, magazynów i lokali publicznych, regulaminowi budowlanemu oraz handlowemu, zakładajaccemu ustalenie cen produktów i przestrzeganie ustalonych godzin działania punktów sprzedaży, porządkowi ruchu ulicznego i konieczności meldunku była tak duża, że w październiku ukarany za nie został prezydent miasta Stanisław Gutt $^{21}$. Skutki nieprzestrzegania przepisów sanitarnych były również dotkliwe dla właścicieli zakładów, czego przykładem było zamknięcie czterech piekarni ${ }^{22}$ : Tepera na ul. Pocztowej pod nr. 8 i 24, Hertzmana na ul. Pocztowej 2 i Sierpickiego na ul. Pijarskiej 2.

${ }_{16}$ Możliwe, że odpowiedź na to pytanie przyniesie kwerenda w archiwaliach chełmskiego magistratu.

17 „Chełmer Sztyme” 1928, nr 3 (149).

18 „Chełmer Sztyme” 1928, nr 37 (181).

19 „Chełmer Sztyme” 1928, nr 16 (162).

20 „Chełmer Sztyme” 1928, nr 39 (183).

21 „Chełmer Sztyme” 1928, nr 42 (186).

${ }^{22}$ „Chełmer Sztyme” 1928, nr 41 (185). 
Krajowe życie polityczne

Rubryka Fun Chetm un umgegent interesowała się nie tylko lokalnym życiem politycznym. W tekstach z marca odnajdziemy informacje na temat wyborów parlamentarnych, które miały się odbyć kilka dni później ${ }^{23}$, m.in. artykuły poświęcone komisjom wyborczym, ważności głosów czy godzinom zamknięcia lokali wyborczych. W kolejnym numerze odnajdziemy opis przebiegu wyborów w mieście ${ }^{24}$ : nastroju pobudzenia, widocznej na ulicach agitacji, wzmożonej aktywności młodzieży, która na ulicach miasta wykrzykiwała hasła wyborcze.

Pod koniec roku tygodnik pisał o wizycie posła na Sejm, prezesa Koła Żydowskiego i działacza syjonistycznego - Izaaka Grünbauma ${ }^{25}$.

\section{Święta oraz uroczystości państwowe i miejskie}

Zebrane tu wydarzenia dotyczyły na równi wszystkich mieszkańców miasta. W czerwcu pisano, że chełmskie władze $\mathrm{z}$ niezrozumiałego powodu nie zdecydowały się na uczczenie obchodzonego na całym świecie dnia kooperatywy ${ }^{26}$. We wrześniu natomiast obchodzono tydzień Międzynarodowego Czerwonego Krzyża ${ }^{27}$.

Najważniejszym wydarzeniem 1928 r. były obchody dziesiątej rocznicy odzyskania przez Polskę niepodległości ${ }^{28}$. Temat przygotowań podją starosta Bagiński, który wezwał wszystkie chełmskie i okoliczne instytucje do wzięcia udziału w przygotowaniach i obchodach. Ostatecznie powołano 13-osobową komisję, w skład której weszło dwóch przedstawicieli tutejszej społeczności żydowskiej, radny Izaak Lederman i prezes gminy wyznaniowej Anszel Biderman.

Szczegółowy program uroczystości obejmował: akademię z udziałem dzieci szkolnych, uroczyste posiedzenie rady miasta, nabożeństwo w Wielkiej Synagodze, defiladę wojskowa, uroczysty pochód zakończony położeniem kamienia węgielnego pod nową szkołę oraz akademię w lokalu gminy wyznaniowej.

W grudniu do chełmskiej gminy przyszło pismo od marszałka Piłsudskiego i prezydenta Mościckiego z podziękowaniem dla społeczności żydowskiej za zorganizowanie i wzięcie udziału w święcie odzyskania

\footnotetext{
23 „Chełmer Sztyme” 1928, nr 9 (155).

24 „Chełmer Sztyme” 1928, nr 10 (156).

25 "Chełmer Sztyme” 1928, nr 49 (193).

26 „Chełmer Sztyme” 1928, nr 24 (170).

27 „Chełmer Sztyme” 1928, nr 36 (180).

28 „Chełmer Sztyme” 1928, nr 41 (185).
} 
przez Polskę niepodległości ${ }^{29}$. Również w grudniu chełmianie uczcili szóstą rocznicę śmierci prezydenta Narutowicza ${ }^{30}$.

\section{Życie religijne}

Zinstytucjonalizowane życie religijne chełmskich Żydów skoncentrowane było wokół gminy wyznaniowej oraz rady gminy, podejmujacej i zatwierdzającej wszelkie decyzje z zakresu funkcjonowania wspólnoty. Tematem roku były bardzo rzadkie posiedzenia, o czym rubryka Fun Chetm un umgegent informuje nas już w styczniu, w artykule pt. Co stychać $w$ żydowskiej gminie ? $^{31}$ Dowiadujemy się z niego o trudnościach $\mathrm{w}$ uchwaleniu budżetu i wewnętrznych tarciach między prezesem i wiceprezesem. Posiedzenia odbyły się zaledwie pięciokrotnie $\mathrm{w}$ ciagu całego roku: dwukrotnie w lutym i trzykrotnie w sierpniu ${ }^{32}$. Podczas pierwszego posiedzenia, w lutym, rada sporządziła sprawozdanie za rok $1927^{33}$. W tym samym miesiacu odbyło się doroczne walne zebranie Towarzystwa Dobroczynnego Linas Hacedek ${ }^{34}$, opiekującego się chorymi. Z kolei dobroczynne Stowarzyszenie Bejt Lechem przygotowywało akcję charytatywną związaną ze zbliżajacym się świętem Pesach $^{35}$, przypadajacym na początek kwietnia. Gmina przekazała na ten cel 1650 zł, Stowarzyszenie dołożyło 500 zł. Z zebranych funduszy zakupiono m.in. ziemniaki i macę, mięso oraz drewno, które zostały przekazane potrzebujacym $^{36}$.

W czerwcu odbyło się doroczne zebranie bezprocentowej kasy pożyczkowej Gemilas Chesed ${ }^{37}$, która miesiąc później została wsparta przez American Jewish Joint Distribution Committee subsydium w wysokości 200 dolarów $^{38}$. W tym samym numerze czytamy również o opiece nad dwójką sierot, jaką roztoczyła gmina żydowska, ustanawiając dla nich specjalny fundusz ${ }^{39}$.

\footnotetext{
29 „Chełmer Sztyme” 1928, nr 50 (194).

30 „Chełmer Sztyme” 1928, nr 51 (195).

31 „Chełmer Sztyme” 1928, nr 3 (149).

32 „Chełmer Sztyme” 1928, nr 6 (152); nr 8 (154); nr 32 (176); nr 34 (178); nr 35

33 „Chełmer Sztyme” 1928, nr 6 (152).

34 "Chełmer Sztyme” 1928, nr 8 (154).

35 „Chełmer Sztyme” 1928, nr 12 (158).

36 „Chełmer Sztyme” 1928, nr 16 (162).

37 "Chełmer Sztyme” 1928, nr 24 (170).

38 "Chełmer Sztyme” 1928, nr 27 (173).

39 „Chełmer Sztyme” 1928, nr 52 (196).
} (179). 
Również w połowie roku miasto odwiedził biskup Adolf Józef Jełowicki $^{40}$, na którego cześć zorganizowano przyjęcie. Biskupa podjęła delegacja powitalna, w której skład weszli rabini Meir Jechiel Najhojz oraz Mosze Adamaszek, a także prezes gminy Anszel Biderman.

We wrześniowym numerze pojawiły się informacje związane z przygotowaniami do obchodów święta Rosz Ha-szana (Nowego Roku). Według tygodnika miasto było nie do poznania w wieczór święta ${ }^{41}$, które wypadało $\mathrm{w}$ połowie września. Pisano również o obchodach kolejnego wielkiego święta jesiennego, Jom Kipur ${ }^{42}$.

W październiku rubryka informowała o otwarciu kuchni w chełmskim domu starców Moszaw Zkenim ${ }^{43}$ (bardzo ciekawe będzie zestawienie tego materiału z zachowanymi sprawozdaniami z działalności tej instytucji). W listopadzie $\mathrm{z}$ kolei była prowadzona zbiórka na rzecz Keren Kajemet le-Israel, czyli Żydowskiego Funduszu Narodowego zbierającego pieniądze na wykup ziemi w Palestynie ${ }^{44}$.

Listopadowy numer informował ponadto przełożonych prywatnych domów modlitwy i sztibli o spoczywajacym na nich obowiązku utrzymania porządku odpowiadającego przepisom sanitarnym ${ }^{45}$, co jest jednym z dowodów potwierdzających, że w mieście żyli chasydzi. Innym dowodem na ich obecność jest informacja związana jednocześnie z życiem politycznym. Otóż w grudniu w sztiblu chasydów turzyskich (trisker) miało miejsce zebranie ortodoksów i chasydów. Poza nimi pojawili się również sympatycy partii Agudat Israel ${ }^{46}$. Zebranie otworzył Bojmgald; Leiner wyraził życzenie, by niedługo w Chełmie pojawiła się lokalna gałąź Agudy, której założenia ideologiczne wyłożył radny Finkelsztein. Wybrano 30-osobową radę, która stać się miała zaczątkiem komitetu organizacyjnego partii w Chełmie ${ }^{47}$.

\section{Życie kulturalne i edukacja}

Obraz chełmskiego życia kulturalnego prezentowany w omawianej rubryce nie jest pełny: informacje o repertuarze kin i teatrów znajduja

\footnotetext{
40 „Chełmer Sztyme” 1928, nr 24 (170).

41 "Chełmer Sztyme” 1928, nr 38 (182).

42 "Chełmer Sztyme” 1928, nr 39 (183).

43 "Chełmer Sztyme” 1928, nr 42 (186).

44 "Chełmer Sztyme” 1928, nr 46 (190).

45 „Chełmer Sztyme” 1928, nr 44 (188).

${ }^{46}$ Związek Izraela (hebr.) - międzynarodowa polityczna organizacja środowisk ortodoksyjnych.

47 „Chełmer Sztyme” 1928, nr 51 (195).
} 
się na innych stronach gazety. Z samej rubryki dowiadujemy się o kilku popularnych lokalach, w których odbywały się wydarzenia kulturalne. Była to m.in.: Resursa (polski klub), gdzie w styczniu odbyła się akademia na cześć jednego z fundatorów ruchu syjonistycznego Dowa Bera Borochowa ${ }^{48}$. Na marginesie dodam, że kilka miesięcy później ${ }^{49} \mathrm{w}$ Chełmie uczczono również rocznicę śmierci głównego ideologa syjonizmu Teodora Herzla. W Resursie odbyła się też akademia w piątą rocznicę śmierci bundysty Władysława Medema ${ }^{50}$.

Inna lokalizacja imprez kulturalnych był kinoteatr Polonia, w którym w lutym odbyły się odczyty działaczy Żydowskiego Klubu Narodowego: Poliakowskiego z Warszawy oraz Wajsbroda z Lublina ${ }^{51}$. W Polonii gościły również trupy teatralne, $\mathrm{w}$ tym uważana za jedną $\mathrm{z}$ najlepszych występujących na prowincji - Izraela Białkowicza i Kurca ${ }^{52}$. Ponadto Polonia była miejscem organizacji uroczystości, np. akademii przygotowanej przez działajace w Chełmie Towarzystwo Odbudowy Palestyny Keren Hajesod ${ }^{53}$.

Z rubryki dowiadujemy się również o działaniu Biblioteki im. Pereca, organizującej m.in. krag książek ${ }^{54}$. Przeczytać możemy też o zebraniach odbywających się w lokalu żydowskiego gimnazjum ${ }^{55}$.

Z kolei Kultur-Lige, o której była już mowa jako o jednej z organizacji dofinansowanych przez radę miasta, przygotowała na Pesach kilka wydarzeń ${ }^{56}$. Jednym $\mathrm{z}$ nich była akademia popularyzująca prawa kobiet, która okazała się dużym sukcesem. Uczestniczki i uczestnicy wysłuchali referatu pani Fryd. Nie sposób stwierdzić, na ile akademia przełożyła się na realia życia chełmskich Żydówek, niemniej z końcem roku grupa „ważnych kobiet naszego miasta”, jak pisała redakcja ${ }^{57}$, powołała Komitet Kobiet. Głównym celem organizacji było wspieranie kobiet znajdujących się w trudnej sytuacji życiowej.

\footnotetext{
48 „Chełmer Sztyme” 1928, nr 1 (147).

49 "Chełmer Sztyme” 1928, nr 28 (174).

50 „Chełmer Sztyme” 1928, nr 5 (151).

51 „Chełmer Sztyme” 1928, nr 8 (154).

52 "Chełmer Sztyme” 1928, nr 47 (191).

53 "Chełmer Sztyme” 1928, nr 49 (193).

54 „Chełmer Sztyme” 1928, nr 15 (161).

55 „Chełmer Sztyme” 1928, nr 40 (184).

56 „Chełmer Sztyme” 1928, nr 16 (162).

57 „Chełmer Sztyme” 1928, nr 52 (196).
} 


\section{Życie gospodarcze}

Najistotniejszym tematem dotyczącym życia gospodarczego całego Chełma w 1928 r. było przeniesienie Dyrekcji Kolei z Radomia do Chełma. Pierwsze wzmianki o takich planach pojawiły się w tygodniku $\mathrm{w}$ marcu $^{58}$. Kolejne miesiace przyniosły dalsze informacje ${ }^{59}$, np. dotyczące utrudnień w przenosinach ${ }^{60}$, wizytacji ministra komunikacji oraz dyrektora kolei, szczegółów dotyczących domów budowanych na osiedlu dla pracowników Dyrekcji ${ }^{61}$, ale również wypadków na placu budowy ${ }^{62}$. $\mathrm{W}$ doniesieniach zwiazanych $\mathrm{z}$ napadami podniesiono watek robotników budujacych osiedle - jeden z nich został oskarżony o napaść na żydowskiego dorożkarza ${ }^{63}$.

W rubryce pisano też o gradobiciach ${ }^{64}$ oraz silnych wyładowaniach powodujaccych pożary ${ }^{65}$, które w omawianym roku „szczęśliwie” omijały miasto, ale już nie jego okolicę.

Pojawiały się również informacje na temat mniejszych inwestycji. Jedna z nich było wybudowanie przez młodego inwestora kiosku6 ${ }^{66}$. Stanał on na wzniesieniu, w miejscu, gdzie ul. Lubelska przecina rynek. Usytuowanie kiosku, którego światła widoczne były z daleka, spowodowało, że chełmianie mieli mówić o nim „chełmski słup ognia”. Niestety, interes zamiast spodziewanych profitów przyniósł właścicielowi niemiłe zaskoczenie - szybko zaczęły do niego trafiać odpadki z okolicznych kramów.

Ponadto dziennikarze piszący do tej rubryki dość często informowali czytelników o działalności operujących w Chełmie banków. Wątek rozpoczęły podjęte na początku roku przez banki decyzje, które zrujnowały chełmskie rodziny żydowskie ${ }^{67}$. Ich echa odnajdziemy w późniejszych miesiącach, kiedy to w tej samej rubryce pisano o samobójstwach spowodowanych trudnymi warunkami finansowymi ${ }^{68}$. W Banku Gospodarstwa Krajowego Zrzeszenie Rzemieślników i Drobnych Kupców ${ }^{69}$ wynegocjowało

\footnotetext{
58 „Chełmer Sztyme” 1928, nr 13 (159).

59 „Chełmer Sztyme” 1928, nr 22 (168); nr 29 (175); nr 33 (177).

60 „Chełmer Sztyme” 1928, nr 15 (161).

61 "Chełmer Sztyme” 1928, nr 43 (187).

62 "Chełmer Sztyme” 1928, nr 42 (186).

63 „Chełmer Sztyme” 1928, nr 50 (194).

${ }^{64}$ "Chełmer Sztyme” 1928, nr 24 (170).

65 „Chełmer Sztyme” 1928, nr 39 (183).

66 „Chełmer Sztyme” 1928, nr 39 (183).

67 „Chełmer Sztyme” 1928, nr 3 (149).

68 „Chełmer Sztyme” 1928, nr 24 (170); nr 50 (194).

69 „Chełmer Sztyme” 1928, nr 12 (158).
} 
niskooprocentowane pożyczki. Na łamach rubryki często pojawiał się watek Banku Kooperatywy ${ }^{70}$. Ponadto w mieście rozpoczęła działalność kooperatywa piekarnicza ${ }^{71}$. W trzecim kwartale wzrostowi miały ulec opłaty mieszkaniowe ${ }^{72}$, wprowadzano także reformy w podatkach i opłatach patentowych ${ }^{73}$.

Innym wątkiem poruszanym przez dziennikarzy były przestępstwa gospodarcze, np. fałszowanie pieniędzy ${ }^{74}$.

\section{Wypadki i sensacje}

Wypadki śmiertelne

W rubryce znalazła się m.in. informacja o tym, że we wrześniu w sztiblu chasydów kazimiersko-modrzyckich ${ }^{75}$ przy ul. Krzywej zmarł nagle modlący się tam Józef Rotblat. Dziennikarz zapisał, że jego śmierć wstrzasnęła tutejszym związkiem handlowym. Nie był to jedyny przypadek niespodziewanej śmierci chełmianina. Zwykle opisom towarzyszyło podanie nazwiska i adresu nieboszczyka, i tak: Chaim Mandelbaum z ul. Krzywej, zupełnie zdrów, zmarł nagle 20 marca $^{76}$. Jesienia zaś zmarli: przy pracy stary operator młyna motorowego przy ul. Trubakowskiej ${ }^{77}$, mieszkaniec ul. Hrubieszowskiej ${ }^{78}$ oraz mieszkanka ul. Pocztowej, niejaka Ribajzen ${ }^{79}$. Listopadowa rubryka ${ }^{80}$ przyniosła szereg dramatycznych wydarzeń: tajemniczy mord, bójkę zakończoną morderstwem oraz nieszczęśliwy wypadek. W kolejnym miesiącu ${ }^{81}$ popełniono zaś morderstwo i samobójstwo.

Niestety, nie zawsze jest jasne, czy opisywane wydarzenie dotyczy chełmskich Żydów, czy chełmian innych wyznań.

\footnotetext{
70 „Chełmer Sztyme” 1928, nr 18 (164); nr 21 (167); nr 31 (175).

71 „Chełmer Sztyme” 1928, nr 50 (194).

72 "Chełmer Sztyme” 1928, nr 28 (174).

73 "Chełmer Sztyme” 1928, nr 21 (167).

74 "Chełmer Sztyme” 1928, nr 38 (182).

75 „Chełmer Sztyme” 1928, nr 38 (182).

76 "Chełmer Sztyme” 1928, nr 12 (158).

77 „Chełmer Sztyme” 1928, nr 39 (183).

78 „Chełmer Sztyme” 1928, nr 42 (186).

79 "Chełmer Sztyme” 1928, nr 44 (188).

80 „Chełmer Sztyme” 1928, nr 46 (190).

81 „Chełmer Sztyme” 1928, nr 49 (193).
} 
Katastrofy budowlane

Najpoważniejszą było zawalenie się domu Benjamina Kupersztoka ${ }^{82}$, o poranku jednego z kwietniowych poniedziałków. W tym stojącym przy ul. Sienkiewicza 10 budynku mieszkały trzy rodziny. Szczęśliwie $\mathrm{w}$ momencie katastrofy $\mathrm{w}$ domu przebywała tylko jedna osoba, żona Sonenstaina, która zdążyła uciec, gdy tylko usłyszała pierwsze trzaski. Z kolei zimą modlaccy się $\mathrm{w}$ szabat $\mathrm{w}$ synagodze usłyszeli wybuch - efekt awarii elektryczności ${ }^{83}$.

Rubryka poruszyła również zagadkowe zniszczenia na chełmskim kirkucie $^{84}-\mathrm{w}$ kwietniu ktoś powyrywał dziesiątki macew z grobów. O zajściu poinformował policję opiekun cmentarza. Policja podjęła śledztwo, jednym z podejrzanych był chrześcijański młodzieniec, który spacerował po cmentarzu. Wydaje się, że nie był on winowajca. Gazeta wymieniała nazwiska pochowanych, których groby zostały zniszczone. Napomknęła również, że podobnie cmentarze były niszczone przez czechosłowackich pogromczikes ${ }^{85}$.

\section{Wypadki komunikacyjne}

Opisy katastrof komunikacyjnych pojawiajace się w wielu numerach „Chełmer Sztyme” moga świadczyć o dość dobrze rozwiniętej infrastrukturze - duża liczba wypadków może oznaczać wielu użytkowników dróg. Lub przeciwnie: mały ruch drogowy powodował, że każdy wypadek nabierał sensacyjnego charakteru.

Wypadki autobusowe miały miejsce $\mathrm{w}$ maju ${ }^{86} \mathrm{i}$ sierpniu $^{87}$, kiedy to autobus linii Lublin - Hrubieszów zabił 75-letnią Fejgę Szor. Kolejna ofiara autobusu kursującego na tej samej trasie była 9-letnia żydowska dziewczynka ${ }^{88}$. Wypadek samochodowy opisano we wrześniowej rubryce $^{89}$. Kilkakrotnie pojawiały się informacje o ofiarach pociagów, jedna z nich był sierżant policji potrącony przez pociąg ${ }^{90}$.

\footnotetext{
82 „Chełmer Sztyme” 1928, nr 14 (160).

83 "Chełmer Sztyme” 1928, nr 5 (151).

84 "Chełmer Sztyme” 1928, nr 17 (163).

85 "Słowo to można przetłumaczyć jako chuligani bioracy udział w pogromach czy napaściach na Żydów. Nie mam żadnych informacji nt. pogromów w Czechosłowacji, sprawa wymaga dalszych badań.

86 „Chełmer Sztyme” 1928, nr 20 (166).

87 "Chełmer Sztyme” 1928, nr 34 (178).

88 "Chełmer Sztyme” 1928, nr 47 (191).

89 „Chełmer Sztyme” 1928, nr 39 (183).

90 "Chełmer Sztyme” 1928, nr 45 (189).
} 
Jedyny wypadek lotniczy z okolicy miał miejsce niedaleko Zamościa ${ }^{91}$. Nie sądzę, by brał w nim udział ktokolwiek z chełmskiej społeczności żydowskiej, przytaczam tę wzmiankę jedynie jako ciekawostkę.

\section{Bójki}

Wątek bójek i napaści powtarzał się w rubryce kilkakrotnie, co może wskazywać albo na problem z przemoca panująca w mieście, albo wręcz przeciwnie: na wyjątkowość takich sytuacji ${ }^{92}$. Przykłady bójek i napaści: latem ${ }^{93}$ na ul. Kopernika został zaatakowany przechodzacy Żyd. Wybuchła awantura i bójka, do której włączały się kolejne osoby. Starcie zakończyło przybycie policji. W tym samym numerze znajdziemy opis bójki pomiędzy włóczęgą i wariatem. Jesienią z kolei gabaj ${ }^{94}$ pobił się z chasydem w sztiblu husiatynerów, podczas piątkowej uroczystości otwierającej szabat ${ }^{95}$. Pewnym problemem było pijaństwo w mieście i okolicy. Pojawiały się informacje na temat bójek czy awantur ${ }^{96}$ wywoływanych przez osoby będące pod wpływem alkoholu, jednak według rubryki dotyczyły one chrześcijańskich mieszkańców Chełma.

\section{Kradzieże}

Opisy kradzieży pojawiły się wyłącznie pod koniec roku: we wrześniu była to kradzież w cerkwi ${ }^{97}$, a w październiku opisano historię sekwestratora, który uciekł z pieniędzmi ${ }^{98}$. Listopad to kolejne doniesienia o kradzieżach ${ }^{99}$, m.in.: w Wielkiej Synagodze ${ }^{100}$, w manufakturze Pinchasa Goldmana przy ul. Lubelskiej 24 oraz przy ul. Trubakowskiej, skąd skradziono ptaki i miód ${ }^{101}$. Ostatnia informacja pochodzi z grudnia: o kradzieży zegara elektrycznego ${ }^{102} \mathrm{z}$ lokalu przy ul. Lubelskiej.

\footnotetext{
91 „Chełmer Sztyme” 1928, nr 44 (188).

92 "Chełmer Sztyme” 1928, nr 38 (182).

93 "Chełmer Sztyme” 1928, nr 24 (170).

${ }_{94}$ Urzędnik gminny pełniący funkcje administratora.

95 „Chełmer Sztyme” 1928, nr 48 (192).

96 "Chełmer Sztyme” 1928, nr 39 (183).

97 "Chełmer Sztyme” 1928, nr 39 (183).

98 "Chełmer Sztyme” 1928, nr 42 (186).

99 „Chełmer Sztyme” 1928, nr 46 (190); nr 47 (191).

100 „Chełmer Sztyme” 1928, nr 45 (189).

101 „Chełmer Sztyme” 1928, nr 48 (192).

102 „Chełmer Sztyme” 1928, nr 49 (193).
} 


\section{Podsumowanie}

Analiza informacji na temat życia codziennego chełmian zawartych w „Chełmer Sztyme” pozwala sformułować tezę, że prasa lokalna z okresu międzywojennego stanowi bogate, niejednokrotnie niezastapione źródło informacji o życiu codziennym. Mimo że zgadzam się z opinią Rocha Sulimy, iż dostęp do minionej codzienności jest właściwie niemożliwy, ze względu na jej ulotny z natury rzeczy charakter ${ }^{103}$, to uważam, że prasa lokalna daje szansę na dotarcie choćby do przebłysków dawnej codzienności.

Prasa lokalna wręcz zaprasza historyka do zastosowania narzędzi i metod analizy antropologicznej. Ten sposób interpretacji danych inspiruje do wyjścia poza faktografię, w kierunku badania społecznego znaczenia opisywanych wydarzeń oraz do głębszej refleksji nad dziennikarskim zapisem rzeczywistości.

Najbardziej chyba zaskakujacym wnioskiem płynacym z relacjonowanych badań jest stosunkowo duże otwarcie Żydów chełmskich na to, co rozgrywało się poza granicami ich społeczności. Wbrew powszechnej opinii o daleko idącej samoizolacji środowisk żydowskich pod względem politycznym, społecznym i kulturalnym prasa żydowska w Chełmie chętnie i dużo pisze o sprawach, które nie dotyczyły bezpośrednio żydowskich mieszkańców miasta.

Podczas kwerendy prasowej natrafiłam również na ciekawy i niezbadany wątek, tj. Żydów zamieszkujących wsie w okolicach Chełma i trudniacych się rolnictwem. Jestem przekonana, że chełmska prasa żydowska, czekająca od lat na nowych czytelników w magazynach warszawskich bibliotek, ujawni wiele nieporuszanych dotąd w badaniach wątków lub pozwoli spojrzeć z innej perspektywy na znane już fakty.

\section{Bibliografia}

\section{Prasa}

"Chełmer Folksblat” 1928-1931;

"Chełmer Sztyme” 1924-1939;

"Chełmer Wochenblat" 1930-1933;

„Echa Szkolne" 1922-1925;

„Unser Cukunft” 1927.

${ }^{103}$ R. Sulima, Antropologia codzienności, Kraków 2000, s. 7. 


\section{Opracowania}

Kiernikowski P., Miasto Chetm $w$ okresie międzywojennym (1918-1939), Chełm 2007.

Kiernikowski P., Mieszkańcy miasta Chetma w latach 1914-1939. Struktura demograficzna i etniczna, „Rocznik Chełmski” 6, 2000, s. 71-88.

Kopciowski A., Wos hert zich in der prowinc? Prasa żydowska na Lubelszczyźnie i jej największy dziennik „Lubliner Tugblat”, Lublin 2015.

Kuwałek R., Żydowskie Gminy Wyznaniowe $w$ powiecie chełmskim $w$ latach 1918-1939, „Rocznik Chełmski” 1, 1995, s. 217-244.

Lubaszewski Z., Spacerkiem po Chetmie, Chełm 2014.

Mandel M., Assimilation and Cultural Exchange in Modern Jewish History, w: Rethinking European Jewish History, red. J. Cohen, M.J. Rosman, Oxford 2014, s. 72-92.

Mart K., Lubaszewski Z., Żydzi w Chełmie, Chełm 2010.

Rosman M.J., How Jewish is Jewish History, Oxford 2007.

Sulima R., Antropologia codzienności, Kraków 2000.

Zieliński K., Ludność ̇̇ydowska w powiecie chetmskim w latach 1914-1918. Studium statystyczne, „Rocznik Chełmski” 2, 1996, s. 185-205.

Zieliński K., Żydzi chetmscy w latach 1912-1918, „Rocznik Chełmski” 3, 1997, s. $203-230$.

Kamila Radecka-Mikulicz

Everyday life of Chełm in 1928 on the basis of "Fun Chełm un umgegent" From Chełm and Its Neighbourhood, column published in the weekly Khelemer Shtime - The Voice of Chełm

(Summary)

The purpose of the article is to sketch out the picture of everyday life of Jewish inhabitants of the town of Chełm in 1928, on the basis of a column "Fun Chełm un umgegent" (From Chełm and Its Neighbourhood) published in the weekly Khelemer Shtime (The Voice of Chełm). The newspaper was published in 1924-1939, but for the purpose of this article I have focused only on issues from one year - 1928 - the most recent year preserved in the collection of the National Library in Warsaw. This limitation enabled a preliminary examination of the weekly's language and its perspective in describing a section of the reality of the town.

This paper is of a contributory character and its main aim is to identify the possibility for using the press in development of a monograph devoted to the Jewish community of Chełm. The subject of inter-war life of the town has been undertaken several times so far, with some researchers interested in the history of Chełm Jews, but there has been no study based on the Chełm press published in the Yiddish language. I am convinced that the Chełm Jewish 
press, for many years waiting for new readers in the storerooms of Warsaw libraries, will reveal many topics that have not been brought up or will shed new light on established facts.

Kamila Radecka-Mikulicz - muzealniczka, interpretatorka, twórczyni koncepcji narracyjnych wystaw historycznych, kuratorka Galerii Zagłada w Muzeum Historii Żydów Polskich POLIN, obecnie kuratorka wystaw w Muzeum POLIN. Absolwentka Instytutu Filozofii Uniwersytetu Warszawskiego. W IH PAN przygotowuje dysertację doktorską poświęconą chełmskiej społeczności żydowskiej w okresie międzywojennym.

Kamila Radecka-Mikulicz - museologist, interpreter, the author of narrative concepts of historical exhibitions, curator of the Holocaust Gallery of the Museum of the History of Polish Jews POLIN, at present the curator of exhibitions at the POLIN Museum. A graduate of the Institute of Philosophy of the University of Warsaw. Currently working on a $\mathrm{PhD}$ dissertation on the Chełm Jewish community in the interwar period at the Institute of History of the Polish Academy of Sciences.

E-mail: kradecka.mikulicz@gmail.com. 